At Norway House we are without the flashing black and white of the Black-billed Magpie so common further south. We had always assumed that House Sparrows were everywhere but find that they are not with us at Norway House. No matter how much of a pest and nuisance these two are, we missed seeing them around this winter. Large flocks of Snow Buittings came through last fall and we assumed they would stay for the winte: but they kept on goingwe guess to delight the greater majority cf bird lovers further south. These last two absentees are interesting because we saw both at The Pas during the Trapper's Festival in late February.

With one exception the birds we have written about were seen away from the settlement of Norway House. That one exception, of course, is the raven which is always around to pick over the garbage. This lack of birds arcund our buildings has made us determined to attract as many birds as possible this spring and summer. To this end the building of bird feeders and bird houses has been the order around our household of late. We are already looking forward to the birds' annual spring return and know that in a few weeks our birdless point on Little Playgreen Lake will be alive with flashing colour and cheerful song.

\section{A SOUTHERLY RECORD OF THE WILLOW PTARMIGAN}

\section{by Robert R. Taylor, Regina}

On February 20, 1964, while driving north on highway No. 6 about seven miles north of Dafoe, I spotted a white grouse-like bird walking on top of a snowdrift at the roadside. I stopped immediately and drove back a short distance to get a better look without disturbing the bird. To my surprise it proved to be a Willow Ptarmigan (Lagopus lagopus), a bird with which I am familiar, having spent a summer in the Northwest Territories where this species is common. Although no binoculars were at hand I watched the ptarmigan for several minutes from about fifty feet away and was able to see that it had fully feathered feet. I also noted that it lacked the black eye-stripe characteristic of the Rock Ptarmigan.

This observation is, I understand, particularly noteworthy as the Willow Ptarmigan is rarely found south of the boreal forest.

Editor's Note: Dafoe is about 90 miles north of Regina and well within the aspen parkland, the nearest boreal forest lying some 60 miles or more to the northeast. $H$. Hedley Mitchell (1924. Birds of Saskatchewan) stated that in some winters ptarmigan had migrated southward into the Upper Transition Zone, i.e., into the parkland, and even "rarely south to the Qu'Appelle Valley." E. Manley Callin has informed us that he has been unable to find a documented record for the Qu'Appelle Valley. At Nipawin, more than 100 miles north of Dafoe, Houston and Street $(1959$. Birds of the Saskatchewan River) report "up to 9 noted during 4 out of 15 Christmas counts", so the species is rare and of irregular occurrence even within the southern edge of the boreal forest.

\section{LATE CHRISTMAS COUNTS}

From Stornoway we have a late report (lette: of February 13) of the Christmas count made December 26, 1963, by Richard and Stanley Zazelenchuk, with the following species listed: Goshawk (1), Sharp-tailed Grouse ( 72 ), Horned Owl (1), Blue Jay (1), Black-billed Magpie (4), Black-capped Chickadee (8), House Sparrow (50), Pine Grosbeak (10), Snow Bunting (6).

Goshawks were also noted this winter at Skull Creek, although the usual Christmas count was not made there, since Steve Mann had just returned from hospital before Christmas. Mr. Mann wrote us (letter of February 10): "I rather felt that I was walking out on one of our pet projects by not compiling a Christmas census, as I had been doing it for so many years, but the only thing that I could have done was travel by car and report birds seen, and that doesn't seem very satisfactory. There have been several Goshawks seen in the neighbourhood this year, the odd Golden Eagle, a Pigeon Hawk, Blue Jay, Canada Jay, large flocks of redpolls, Snow Buntings, and Horned Larks. No one has seen very many grosbeaks, either Pine or Evening. Chickadees are quite numerous up and down the creek. We have had ten or twelve at our feeding trays, near the house, all winter." 